\title{
ANALISIS KUALITATIF KANDUNGAN BUNGA KENANGA (Cananga odorata) SECARA FITOKIMIA dengan MENGGUNAKAN PELARUT ETANOL
}

\author{
Aisyah Meisya Putri ${ }^{1}$, Anasthasia Oca Muham ${ }^{2}$, Silvia Anggraini ${ }^{3}$, Siti Maisarmah ${ }^{4}$, \\ Putri Ade Rahma Yulis ${ }^{5}$ \\ Program Studi Pendidikan Kimia, Universitas Islam Riau \\ *Email: aisyah@student.ac.uir.id; *Phone: 085272778895
}

\begin{abstract}
Abstrak
Tanaman kenanga (Cananga odorata) merupakan tanaman pohon atau perdu yang bunganya dapat dimanfaatkan untuk menghasilkan minyak atsiri. Pada penelitian ini dilakukan uji kualitatif secara fitokimia untuk mengetahui kandungan metabolit sekunder pada bunga kenanga. Berdasarkan hasil penelitian bunga kenanga positif mengandung flavonoid, tanin, saponin dan steroid, sementara untuk antrakuinon dan terpenoid tidak terdeteksi. Adanya kandungan metabolit sekunder pada tanaman ini memungkinkan untuk dijadikan bahan baku berpotensi obat karena adanya kandungan metabolit aktif yang mengindikasikan tanaman tersebut mempunyai aktvitas antioksidan ataupun antibakteri lainnya.
\end{abstract}

Kata kunci : bunga kenanga, ekstraksi, uji fitokimia

\begin{abstract}
Cananga (Cananga odorata) is a tree or shrub that can be used to produce essential oils. In this study a qualitative test was conducted to study the content of secondary metabolites in cananga flowers. Based on research results cananga flowers contain flavonoids, tannins, saponins and steroids, while anthraquinone and terpenoids are not needed. The existence of secondary metabolite content in this plant is intended to be used as a raw material needed because it has an active metabolite content that links this plant to have antioxidant and other antibacterial properties.
\end{abstract}

Keywords: Ylang flowers, extraction, phytochemical test

\section{Pendahuluan}

Tanaman kenanga (Cananga odorata) merupakan salah satu jenis tanaman penghasil minyak atsiri (Anggia et al., 2018). Tanaman kenanga yang terdapat di Indonesia adalah jenis Canangaodorata. Ada dua forma kenanga, yakni Cananga odorata formagenuina atau kenanga Filipina, yang juga disebut ylang-ylang (Rini pujiarti, Titis Budi Widowati, Kasmudjo, 2015).

Minyak kenanga merupakan salah satu jenis minyak atsiri yang memiliki aroma yang khas yaitu beraroma floral dan berwarna kuning muda hingga kuning tua (Supartono, 2014). Khasiat bunga kenanga adalah sebagai obat penyakit kulit, asma, anti nyamuk, antibakteri dan antioksidan (Dusturia et al., 2016). Bunga kenanga merupakan salah satu tanaman yang bisa digunakan sebagai obat tradisional. Ekstrak bunga kenanga memiliki efek sebagai antioksidan, antimikroba, antibiofilm, anti inflamasi, antivektor, repellent, antidiabetes, antifertilitas dan antimelanogenesis ( $\mathrm{Ni}$ nyoman Wahyu Udayani, Herleeyana merliyani, 2017). 
Berdasarkan uraian di atas, pada penelitian ini dilakukan uji kualitatif kandungan bunga kenanga. Sebelum proses identifikasi terlebih dahulu dilakukan proses ekstraksi dengan maserasi yang merupakan metode sederhana yang paling banyak digunakan. Cara ini sesuai, baik itu skala kecil maupun skala industri (Mukhriani, 2014). Karena selama ini bunga kenanga jarang diolah dan hanya dimanfaatkan sebagai tanaman hias oleh masyarakat, sehingga akan lebih baik diolah menjadi sesuatu yang lebih bermanfaat dan memiliki nilai jual yang tinggi. Selain itu beberapa penelitian lainnya terkait bunga kenanga telah dilakukan diantaranya ekstraksi bunga kenanga sebagai aroma terapi sabun cair (Anggia et al., 2018), ekstraksi minyak kenanga untuk lotion penolak serangga (Supartono, 2014), esktraksi minyak atsiri bunga kenanga untuk parfum dan lotion anti nyamuk (Setia Budi et al., 2018). Sejauh ini yang telah diteliti penggunaan nya terkait pemanfaatan minyak atsiri nya. Pada penelitian ini dilakukan uji fitokimia kandungannya dengan harapan informasi kandungan metabolit sekunder ini dapat menjadi landasan untuk diolah menjadi bahan-bahan lainnya yang lebih potensial terutama untuk bahan baku obat.

\title{
Metodologi Penelitian
}

\section{Bahan}

Etanol $96 \%$, aquades, kloroform, methanol $90 \%$, asam sulfat pekat, asam klorida pekat, amoniak $10 \%$, besi (III) klorida $1 \mathrm{M}, \mathrm{MgCl}_{2} 1 \mathrm{M}$.

\begin{abstract}
Alat
Gelas piala, tabung reaksi, rotary evaporator, kertas saring Whatman no 1, neraca digital, mortir, rak tabung reaksi, pipet tetes, pipet volum, bola hisap, aluminium foil, bunsen, kaki tiga, kawat kasa, penjepit kayu.

\section{Prosedur}

\section{Preparasi Sampel}

Bunga kenanga berwarna kuning/hijau dipetik dan diletakkan pada wadah terbuka selama \pm 7 hari diruangan yang terpapar sinar matahari hingga kering dan berwarna kehitaman, kemudian dihaluskan menggunakan mortir hingga halus. Prosedur ini dilakukan mengikuti penelitian Udayani, dkk (2017) dan Ramdan dan Purnamasari (2016) dengan sedikit modifikasi.
\end{abstract}

\section{Ekstraksi}

Sebanyak 41 gram sampel berupa serbuk halus bunga kenanga (Cananga odorata) dimaserasi dengan $200 \mathrm{~mL}$ etanol 96\% selama 24 jam, kemudian campuran tersebut di filtrasi. Filtrat dipekatkan dengan rotary evaporator pada suhu $40^{\circ}$ dengan kecepatan 65 
rpm selama 17 menit sehingga menghasilkan ekstrak kental etanol bunga kenanga. Selanjutnya dilakukan uji fitokimia pada ekstrak kental etanol bunga kenanga.

\section{Uji Fitokimia}

Prosedur yang dilakukan pada penelitian ini merujuk pada jurnal penelitian oleh Ramdan dan Purnamasari (2016) dengan sedikit modifikasi dan penyesuaian kesediaan bahan

\section{Uji Flavonoid}

$1 \mathrm{~mL}$ sampel lalu ditambahkan $1 \mathrm{~mL}$ etanol dan dipanaskan dalam tabung reaksi di atas penangas. Larutan tersebut disaring sehingga filtratnya terpisah dari larutan, lalu filtrate tersebut ditambahkan 3 tetes $\mathrm{HCl}$ pekat dan ditambahkan lagi $\mathrm{MgCl}_{2}$ dan kemudian diamati perubahan yang terjadi. Hasil positif uji flavonoid ditandai dengan adanya perubahan warna kemerahan sampai orange.

\section{Uji Tanin}

$1 \mathrm{~mL}$ sampel (bunga kenangan) dimasukkan ke dalam tabung reaksi, kemudian ditambahakan $1 \mathrm{~mL}$ etanol, dan didiamkan, lalu disaring ke dalam tabung reaksi, diambil $1 \mathrm{~mL}$ filtrat, kemudian ditambahkan $1 \mathrm{~mL}$ aquadest dan $1 \mathrm{~mL} \mathrm{FeCl}$. Hasil positif uji tanin ditandai dengan terbentuknya warna hijau kehitaman.

\section{Uji Antrakuinon}

$1 \mathrm{~mL}$ sampel lalu ditambah dengan $1 \mathrm{~mL}$ etanol. Campuran tersebut disaring menggunakan kertas saring. Kemudian ditambah $1 \mathrm{~mL}$ larutan amoniak, lalu dikocok. Hasil positif uji antrakuinon ditandai dengan adanya perubahan warna merah.

\section{Uji Saponin}

$1 \mathrm{~mL}$ sampel dimasukkan ke dalam tabung reaksi dan ditambah aquadest sebanyak 1 $\mathrm{mL}$. Campuran tersebut didihkan sampai 2-3 menit. Didinginkan dan dikocok dengan kuat. Hasil positif uji saponin ditandai dengan timbulnya busa.

\section{Uji Steroid}

$1 \mathrm{~mL}$ sampel ditambahkan $1 \mathrm{~mL}$ kloroform lalu dikocok, kemudian ditambah 3 tetes $\mathrm{H}_{2} \mathrm{SO}_{4}$ pekat. Hasil positif uji steroid ditandai dengan adanya perubahan warna coklat

\section{Uji Triterpenoid}

$1 \mathrm{~mL}$ sampel ditambah $1 \mathrm{~mL}$ methanol lalu dikocok, selanjutnya ditambah $1 \mathrm{~mL}$ kloroform dan 5 tetes $\mathrm{H}_{2} \mathrm{SO}_{4}$ pekat. Hasil positif uji triterpenoid ditandai dengan adanya perubahan warna merah. 


\section{Hasil dan Pembahasan}

Proses ekstraksi khususnya untuk bahan yang berasal dari tumbuhan dimulai dengan pengelompokan bagian tumbuhan (daun, bunga, dan lain-lain), pengeringan dan penggilingan bagian tumbuhan, pemilihan pelarut (Mukhriani, 2014). Proses maserasi dipilih pada penelitian dengan tujuan dapat menghindari rusaknya senyawa-senyawa yang bersifat termolabil.

\section{Hasil Uji Fitokimia}

Bunga kenanga di ekstrak dengan etanol karena pelarut ini sangat baik dalam melarutkan senyawa metabolit sekunder dari sumbernya. Hasil uji fitokimia di sajikan pada Table 1 dan Gambar 2.

Tabel 1. Hasil uji fitokimia ekstrak etanol bunga kenanga (Cananga odorata)

\begin{tabular}{c|c|c|c}
\hline No & Jenis Uji Fitokimia & Hasil Pengamatan & Hasil pengujian \\
\hline 1. & Uji flavonoid & Merah keunguan & + \\
\hline 2. & Uji Tanin & Hijau kecoklatan & + \\
\hline 3. & Uji antrakuinon & Kuning & + \\
\hline 4. & Uji saponin & $\begin{array}{c}\text { Kuning keruh, sedikit } \\
\text { berbusa }\end{array}$ & + \\
\hline 5. & Uji steroid & Coklat gelap & - \\
\hline 6. & Uji triterpenoid & Hitam & + \\
\hline
\end{tabular}

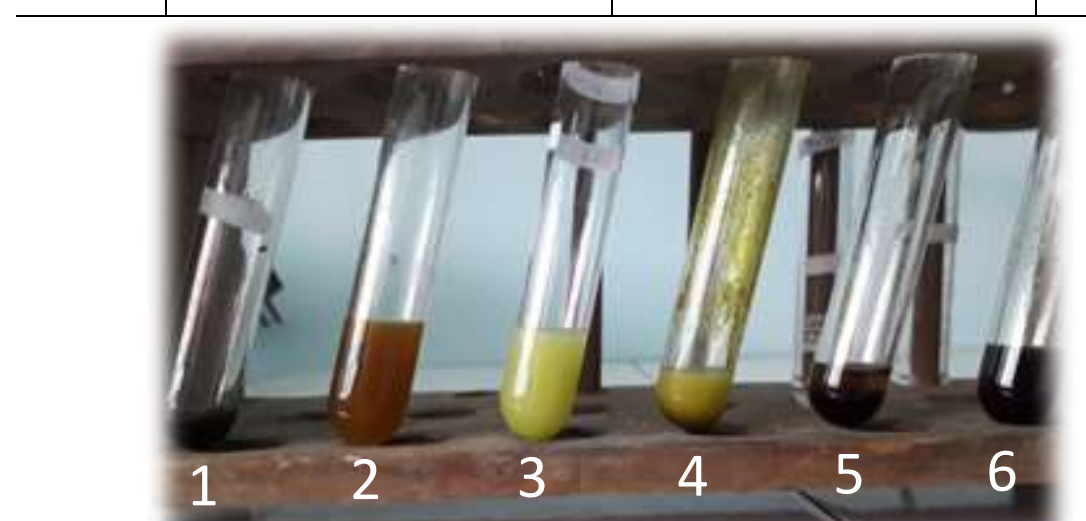

Gambar 2. Hasil uji fitokimia terhadap ekstrak etanol bunga kenanga, 1. Uji Flavonoid; 2. Tannin; 3. Antrakuinon; 4. Saponin; 5. Steroid; dan 6. Triterpenoid

Flavonoid adalah senyawa metabolit sekunder yang biasanya berupa zat warna merah, ungu dan biru pada bunga. Hasil uji untuk mendeteksi flavonoid ditandai dengan warna merah tua pada larutannya. Uji flavonoid pada bunga kenanga menghasilkan warna merah keunguan yang menandakan adanya senyawa flavonoid pada bunga kenanga. Uji kandungan tanin dilakukan dengan bantuan senyawa etanol dan $\mathrm{FeCl}_{3}$. 
Adanya tanin pada suatu zat ditandai dengan terbentuknya warna hijau kehitaman atau kehitaman saja. Pada bunga kenanga terdapat warna hijau kecoklatan, ini menandakan adanya tanin pada ekstrak bunga kenanga. Tanin diketahui mempunyai manfaat yang beragam seperti astrigen, anti diare, anti bakteri dan anti oksidan.

Hasil positif pada uji antrakuinon ditandai dengan adanya perubahan warna merah pada larutan. Senyawa ini dikenal sebagai senyawa obat atau senyawa antiradikal bebas. Uji antrakuinon pada bunga kenanga menghasilkan warna kuning keruh yang menandakan bahwa antrakuinon tidak terdeteksi pada bunga kenanga. Uji saponin ditandai dengan adanya busa pada larutan saat dikocok. Pada ekstrak etanol bunga kenanga busa yang dihasilkan hanya dalam jumlah sedikit. Kemungkinan dikarenakan kandungan nya yang cukup rendah.

Hasil positif uji steroid ditandai dengan perubahan warna menjadi biru kehitaman atau hijau pada larutannya. Ekstrak etanol bunga kenanga menunjukkan adanya senyawa steroid dengan hasil coklat gelap pada larutannya. Uji triterpenoid merupakan uji metabolit sekunder yang ditandai dengan adanya perubahan warna merah pada larutannya. Hasil pada ekstrak etanol bunga kenanga menunjukkan hasil negative pada uji ini. Warna yang dihasilkan pada uji ini adalah warna hitam. Steroid tidak terdapat bebas tetapi sebagai turunan senyawa yang lebih rumit seperti seperti glikosida atau ester dengan asam lemak/asam aromatik.

Berdasarkan hasil yang didapatkan dari uji secara kualitatif dengan skrining fitokimia bahwa pada esktrak etanol bunga terdapat senyawa metabolit sekunder yang cukup banyak diantaranya positif flavonoid, tanin, saponin dan steroid. Kandungan flavanoid dan saponinnya bersifat antibakteri dan antiinflamasi. Flavonoid merupakan golongan terbesar dari senyawa fenol yang mempunyai sifat efektif menghambat pertumbuhan virus, bakteri dan jamur (Dusturia et al., 2016). Dengan adanya senyawa ini maka bunga kenanga dapat dijadikan bahan baku berpotensi obat karena kemungkinan mengandung antioksidan ataupun antibakteri yang cukup tinggi. Antioksidan dapat menangkal radikal bebas yang ada di tubuh, sehingga dapat mencegah sel kanker muncul dan berkembang. Sedangkan, antibakteri dapat membunuh bakteri yang menempel pada permukaan kulit dan pakaian, sehingga dapat dijadikan handsanitaizer.

\section{Kesimpulan}

Ekstrak etanol bunga kenanga mengandung flavonoid, tanin, steroid dan saponin yang merupakan senyawa metabolit skunder yang dibuktikan dengan uji fitokimia, sehingga dapat diolah menjadi bahan baku produk lainnya yang lebih potensial. Agar dapat menjadi produk lainnya bunga kenangan akan lebih baik apabila dijadikan minyak atsiri terlebih dahulu, setelah itu bisa diolah menjadi berbagai macam produk. Untuk penelitian selanjutnya dapat dianalisis kandungannya dari parameter yang lain serta kandungan tanaman secara kuantitatif. 


\section{Daftar Referensi}

Anggia, M., Mutiar, S., \& Arziah, D. (2018). Teknologi Ekstraksi Bunga Kenanga (Cananga Odorata L.) dan Sereh Wangi (Cymbopogon Nardus L. ) Sebagai Aroma Terapi Sabun Cair. Jurnal Daur Lingkungan, 1(1), 5. https://doi.org/10.33087/daurling.v1i1.2

Dusturia, N., Hikamah, S. R., \& Sudiarti, D. (2016). Efektivitas Antibakteri Bunga Kenanga (Cananga Odorata) Dengan Metode Konvensional Terhadap Pertumbuhan Staphylococcus aureus. Bioshell, 5(01), 324-332.

Mukhriani. (2014). Ekstraksi, pemisahan senyawa, dan identifikasi senyawa aktif. Jurnal Kesehatan, VII(2), 361-367.

Ni nyoman Wahyu Udayani, Herleeyana merliyani, K. agus adrianta. (2017). Efektivitas bunga kenanga (cananga odorata hook.f \& th) sebagai hepatoprotektor pada tikus putih ( rattus norvegicus) yang diinduksi carbon tetra chloride. Medicamento, 3(2), 84-90.

Rini pujiarti, Titis Budi Widowati, Kasmudjo, \& S. sunarta. (2015). Kualitas, komposisi kimia, dan aktivitas antioksidan minyak kenanga (. Jurnal IImu Kehutanan, 9(1), 311.

Setia Budi, J. J., Yuli Damayanti, N. L., Dhani, Y. R., \& Antari Dewi, N. P. (2018). Ekstraksi dan karakterisasi minyak atsiri bunga kenanga (cananga odorata) dan aplikasinya sebagai penolak nyamuk pada lotion dan parfum. Jurnal Kimia, 19. https://doi.org/10.24843/jchem.2018.v12.i01.p04

Supartono, G. W. P. S. (2014). EKSTRAKSI MINYAK KENANGA (Cananga odorata) UNTUK PEMBUATAN SKIN LOTION PENOLAK SERANGGA. Jurnal MIPA, 37(1), 62-70. 